\title{
Water in Mining and Environment for Sustainability
}

\author{
Nural Kuyucak ${ }^{1}$ \\ Received: 17 April 2021 / Accepted: 12 August 2021 / Published online: 24 August 2021 \\ (c) Springer-Verlag GmbH Germany, part of Springer Nature 2021
}

Acid mine drainage (AMD) at mining sites has caused governments, industries, and research organizations to identify and investigate preventive measures and to develop technologies to manage mining wastes and mine water since the late 1970s. In Canada, a program called Mining Environment Neutral Drainage (MEND) was initiated in 1983 as a consortium of federal and provincial governments, mining associations, industry, and research organizations, with a mandate to develop prevention and control methods and treatment options for AMD. The MEND program raised awareness and created an international interest that included the USA and Australia. Noranda Minerals Inc., one of the largest natural resource companies in Canada at the time, participated in the MEND program by developing AMD control and prevention methods, treatment options, and monitoring strategies. Laboratories were set up at the Noranda Technology Centre (NTC), Pointe Claire, Quebec, to develop chemical, biological, and physical methods to treat AMD. The results were shared through publications and presentations (Kuyucak 1998).

Chemical treatment using lime (calcium hydroxide, $\mathrm{Ca}(\mathrm{OH})_{2}$ ) for neutralization was easily adaptable to different sites, but the resulting waste sludge containing metal hydroxides and gypsum was an issue because of its large volume, requiring long storage times and management. Researchers developed a high-density sludge (HDS) process in the 1960s (Kostenbader and Haines 1970). In this process, a portion of sludge would be recycled to the lime slurry and to be used for neutralization process. The resulting sludge from HDS was less voluminous in comparison to the straight neutralization process. The sludge and its formation with different methods were investigated, and its structure was observed at the molecular level (Kuyucak et al. 1991a, b). The results revealed that crystallization of gypsum $\left(\mathrm{CaSO}_{4}\right)$ could consolidate the sludge structure by making it chemically more

Nural Kuyucak

nural.kuyucak@gmail.com

1 Golder Associates Ltd, Ottawa, Canada stable and less voluminous. Because of its less viscosity, it was easier and less expensive for pumping, transporting and managing. Based on the new research results, a new HDS process was developed in which the neutralization of the acid water, especially one with high concentrations of sulphate ions, iron and other metals, could be carried out in two stages (Kuyucak and Sheremata 1995). Per classic HDS, the acid water is first neutralized to a $\mathrm{pH}$ of $4-4.5$ with recycled sludge, which provides nuclei for crystallization and ferric iron precipitates and offer adsorption sites to metal ions. In the second step, the partially neutralized and reasonably diluted water was neutralized with a mixture of sludge and lime in the presence of aeration to a desired $\mathrm{pH}$ level, usually a $\mathrm{pH}$ of 9-9.5, where most cations, such as $\mathrm{Fe}^{2+}, \mathrm{Zn}^{+}$, and $\mathrm{Cu}^{2+}$ precipitated, allowing the regulated limits to be met in the separated clear water. A mini-pilot plant was constructed and tested at several Noranda group mining sites (Kuyucak and Payant 1995). Based on the successful results, the process was scaled up and commissioned at several mining sites around the world such as: Geco Mattabi Mine, Ontario Canada; Kristineberg, Boliden Minerals, Sweden (Kuyucak et al. 2001a, b); Falun Stora Mine, Sweden (Kuyucak et al. 2005); Apirsa Boliden Minerals, Spain (Kuyucak et al. 1999).

In addition, a ferric iron co-precipitation process for the treatment of wastewaters containing molybdenum (Mo), arsenic (As), and selenium (Se) and neutralization with sodium sulphide $\left(\mathrm{Na}_{2} \mathrm{~S}\right)$, was developed to meet even more stringent limits. More efficient aeration and filtration methods were studied. In collaboration with McGill University, oxidation of ferrous iron $\left(\mathrm{Fe}^{2+}\right)$ to ferric iron $\left(\mathrm{Fe}^{3+}\right)$ and other possible options were examined (Kuyucak and Payant 1995). Oxidation of $\mathrm{Fe}^{2+}$ with air at $\mathrm{pH}>8$, was found to be the most feasible method (Rao et al. 1994). Biosorption, ion exchange, and membrane processes were also investigated as potential ways to treat mining waters and AMD (Kuyucak et al. 1989, Kuyucak 1998).

Next, sludge compaction was studied for sludge management. Freeze-thaw was found to be the best option for cold climates and a staged disposal method provided the 
best results. Ice formation pushes the metal hydroxide and gypsum particles together. After thawing, the melting ice drains, leaving compact particles and a porous sludge texture behind. Staged disposal where two or three disposal plots were alternately used produced a more compact, less voluminous sludge for storage. In addition, possible recovery of metals and gypsum from the sludge was investigated (Rao et al. 1994).

The Noranda Technology Centre pioneered the development of processes using sulphide-reducing bacteria (SRB) for treating AMD. Although AMD treatment in wetlands and the role of wetland plants and bacteria were investigated, the prime emphasis was given to the use of SRB. Treating acid water in situ as well as preventing further AMD generation in situ in open pits by SRB were explored and a process was developed (Kuyucak and St-Germain 1994a, b; Kuyucak et al. 1991c). In addition to the investigation of engineering parameters, suitable nutrient sources including hay, manure, sawdust, peat, litters, alfalfa, bark, paper pulp, and their mixtures were examined (Kuyucak and StGermain 1993). The required nutrient source had to contain carbon, nitrogen, and phosphorus in certain proportions and slowly released. A mixture of sawdust, manure, and hay were selected for scale-up studies. The use of SRB in reactors under controlled conditions using molasses or whey and anoxic limestone drains, aeration and precipitation systems as passive methods for treating seepages, were investigated (Kuyucak and St-Germain 1994c).

Combinations of biological treatment options with water covers was explored to prevent AMD generation in situ (StGermain and Kuyucak 1998). Later, these biological methods were applied at several mine sites (Kuyucak 2002). Treatment of seepage with a passive SRB system was successfully applied by Golder Associates at a site in northern Quebec, Canada, where winter temperatures could be below $40{ }^{\circ} \mathrm{C}$ (Kuyucak et al. 2006; Kuyucak and Chabot 2010). A mixture of sawdust, manure, hay, and lime were used as nutrients. The design was based on an up-gradient, trickling filter principle. The top of the system was covered with a layer of plastic fabric, Styrofoam, and soil for heat insulation and to prevent water infiltration from rain and snow precipitation. One of the factors for the successful implementation was the preparation and conditioning of the nutrients during warm temperatures prior to the start-up of the system.

With the help of funding from the Canadian International Development Agency (CIDA), Golder Associates investigated the possible use of treated AMD from the Kingsmill Tunnel to supplement the drinking water supply of Lima, Peru (Kuyucak et al. 2003). The studies involved site investigation, suitable treatment technology selection, pilot tests, analysis of technical and economic feasibility, potential environmental and social impact, and preliminary design. The quality of treated water was examined by chemical and biological analyses. We found that AMD treated with HDS lime neutralization produced a water quality that was suitable for mixing with the source, which could be sent to the water treatment plant for its distribution as drinking water. Staged sludge disposal was a feasible method for sludge management at the site (Kuyucak et al. 2004).

Recycling and reuse of process water could make mining operations more sustainable and minimize adverse effects on the environment by reducing the need for freshwater resources and the amount of discharge to the environment. The presence of thiosalts (reduced sulphide species) in process waters create issues when the water is discharged to water resources. Thiosalts continue to oxidize in the water resource resulting in significant acidification and harming the biological life (Kuyucak et al. 2001a, b). Lime neutralization with carbonate buffering was found be a viable option to prevent a $\mathrm{pH}$ drop in water and a portion of it could be used at some stages of metallurgical processes (Kuyucak and Yaschyshyn 2007).

Degradation of cyanide is an important issue for gold and precious metal mining. Chemical, biological, and passive methods have been tried as a remedy at many mine sites. Growing algae in the pits and enhanced oxidation in the tailings ponds were identified to be the most feasible options for the Canadian mining sites, as they allowed the construction of large ponds. The mine water resulting from Noranda's gold mine located in environmentally sensitive sites required total nitrogen (ammonia $\left(\mathrm{NH}_{4}^{-}\right.$) and nitrate $\left[\mathrm{NO}_{3}{ }^{-}\right]$) levels to be less than $0.5 \mathrm{mg} / \mathrm{L}$ at the discharge. The Noranda Technology Centre developed a biological process for treating the mine water, built a pilot system to test the process, and subsequently used it at the site.

\section{Conclusion}

Management and treatment of mining waters and AMD to the required water quality limits are essential for the successful operation and responsibly protecting the environment. Several conventional and established methods of treatment are available; nevertheless, research continues to explore other innovative and more feasible alternatives to the existing ones. Reusing and recycling treated mine water back to the mining and metallurgical processes will make the mining a more sustainable industry. The use of treated AMD to supplement to drinking water sources, instead of discharging it to the environment, expands the horizons in the field of mine water management and treatment.

Acknowledgements The studies and processes described above were carried out by the author during her employment at Noranda Technology Centre as Group Leader for Treatment Technologies, and Golder Associates Ltd., Ottawa Office, as Senior Engineer and Project Manager. She closely worked with MEND and collaborated on several 
research projects. This summary aims to provide a Canadian perspective on mine water and AMD management and treatment. She has taken her retirement, but still undertakes some consulting work.

\section{References}

Kostenbader PD, Haines GF (1970) High density sludge treats acid mine water, Coal Age, September, p 90

Kuyucak N (1998) Mining, the environment and the treatment of mine effluents. Int J Environ Poll 10(2):315-325

Kuyucak N (2002) Review-the role of microorganisms in mining: generation of acid rock drainage, its mitigation and treatment. Eur $\mathbf{J}$ Miner Process Environ Prot 2(3):179-196

Kuyucak N, Chabot F (2010) Effective passive treatment systems in extremely cold climatic conditions. In: Proceedings of 100 years of mining research symposium, 2010 SME, pp 434-438

Kuyucak N, Payant S (1995) Enhanced lime neutralization methods for improving sludge density and final effluent quality. In: Rao SR, Amaratunga LM, Richards GC, Kondos PD (eds) Waste processing and recycling in mineral and metallurgical industries. Proceedings of CIM conference, vol II, pp 382-392

Kuyucak N, Sheremata T (1995) Lime neutralization process for treating acid waters. US Patent: 5,427,691

Kuyucak N, St-Germain P (1993) Passive treatment methods for acid mine drainage. In: Hager JP (eds) Proceedings of EPD congress, pp 319-331

Kuyucak N, St-Germain P (1994a) In-situ treatment of acid mine drainage by sulphate reducing bacteria in open pits: scale-up experiences. In: International land reclamation and mine drainage conference and proceedings of 3rd ICARD, vol 2, pp 303-310

Kuyucak N, St-Germain P (1994b) Possible options for in-situ treatment of acid mine drainage seepages. In: Proceedings of international land reclamation and mine drainage conference and 3rd ICARD, vol 2, pp 311-318

Kuyucak N, St-Germain P (1994c) Evaluation of sulphate reducing bacteria and related process parameters for developing a passive treatment method. In: Holmes DS, Smith RW (eds) Proceedings of engineering foundation conference, pp 287-302

Kuyucak N, St-Germain P (1989) Biologically supported water covers "Conceptual Process Development to Prevent Acid Generation in Tailings Ponds". Min. Pro. Ext. Met. Rev., December 1998, p 1-13

Kuyucak N, Yaschyshyn D (2007) Managing thiosalts in mill effluents, studies conducted at the Kidd metallurgical site. In: Proceedings of mining and the environment IV conference, pp 107-116

Kuyucak N, Sheremata T, Wheeland KG (1991a) Evaluation of improved lime neutralization process: part 1-lime sludge generation and stability. In: Proceedings of MEND 1991 and 2nd ICARD, vol 1, pp 26-31

Kuyucak N, Mikula RJ, Wheeland KG (1991b) Evaluation of improved lime neutralization process: part 3-interpretation of properties of lime sludge generated by different processes. In: Proceedings of MEND 1991, 2nd ICARD, vol 1, pp 31-33

Kuyucak N, Lyew D, St-Germain P, Wheeland KG (1991c) In situ bacterial treatment of AMD in open pits. In: Proceedings of MEND 1991 and 2nd, vol 1, pp 336-353

Kuyucak N, Lindvall M, Serrano JAR, Oliva AF (1999) Implementation of a high density sludge "HDS" treatment process at the Boliden Apirsa mine site. In: Proceedings of clean technologieswastewater treatment symposium, pp 473-479

Kuyucak N, Lindvall M, Sundqvist T, Sturk H (2001a) Implementation of a high density sludge "HDS" treatment process at the Kristineberg mine site. In: Proceedings of securing the future, international conference on mining and the environment conference, pp 1-11

Kuyucak N, Serrano JRA, Hultqvist J, Ericksson N (2001b) Removal of thiosalts from mill effluents. In: Rao SR, Amaratunga LM, Richards GC, Kondos PD, Kuyucak N, Kozinski JA (eds) Proceedings of, 4th international symposium on waste processing and recycling in mineral and metallurgical industries CIM conference, pp 481-495

Kuyucak N, Chávez J, del Castillo JR, Ruiz J (2003) Technical feasibility studies and uses of treated AMD at Kingsmill Tunnel, Peru. In: Proceedings of 6th ICARD, Cairns, Australia, pp 771-779

Kuyucak N, Chávez J, del Castillo JR, Ruiz J (2004) Potential use of treated acid mine drainage at Kingsmill Tunnel, Peru-technical and economic feasibility studies. In: 5th International symposium on waste processing and recycling in mineral and metallurgical industries, CIM conference, pp 541-552

Kuyucak N, Mattsson E, Bringsaas H (2005) Implementation of a sitespecific high density sludge process for treating high strength acid mine drainage at Falu mine site, Falun, Sweden. In: Proceedings of securing the future, international conference on mining and the environment, metal and energy recovery, pp 546-555

Kuyucak N, Chabot F, Martschuk J (2006) Successful implementation and operation of a passive treatment system in extremely cold northern Quebec, Canada. In: Barnhisel RI (eds) Proceedings of 7th international conference on the abatement of acidic drainage (ICARD), St. Louis, USA, pp 980-992

Rao SR, Kuyucak N, Sheremata T, Leurux M, Finch JA, Wheeland KG (1994) Prospect of metal recovering/recycling from acid mine drainage. In: International land reclamation and mine drainage conference and proceedings of 3rd ICARD, vol 1, pp 223-232

St-Germain P, Kuyucak N (1998) Biological water covers-a preliminary assessment. Miner Process Exte Metall Rev 19(1-4):39-46

Publisher's Note Springer Nature remains neutral with regard to jurisdictional claims in published maps and institutional affiliations. 